\title{
PENYEMBUHAN LUKA PERINEUM DENGAN SENAM NIFAS
}

\author{
Henny Prihatni ${ }^{1}$, Yulistiana Evayanti ${ }^{2}$, Devi Kurniasari ${ }^{3}$, Sunarsih $^{4}$ \\ 1,21Program Studi DIV Kebidanan Fakultas kedokteran Universitas Malahayati Bandar Lampung \\ 1email : hennyismet99@gmail.com, \\ 2emailyulistianaevayanti@gmail.com, \\ 3,4Program Studi DIII Kebidanan Universitas Malahayati Bandar Lampung \\ 3emaildevikurniasari82@gmail.com , \\ ${ }^{4}$ email sunarsih@malahayati.ac.id
}

\begin{abstract}
Background Labor and delivery are physiological events. Often childbirth causes birth canal injuries so that it must be cared for properly and properly The maternal mortality rate in Lampung in 2017 is still high, namely 115.8 per 100,000 live births. The results of the initial survey in January 2019 at BPM Siti Hajar, S.ST, Desa Merak Batin Natar District, South Lampung Regency, that in January there were 52 post partum mothers, of the 52 post partum mothers 40 of them had perineal injuries, 37 due to spontaneous rupture and 3 due to episiotomy.

Purpose was to determine the effect of postpartum gymnastics on the healing of perineal wounds in postpartum mothers at BPM Siti Hajar, S.ST, Merak Batin Village, Natar District, South Lampung Regency in 2019.

Methods Quantitative research type methods, pre-experimental research design with a static group comparison approach. The population was 52 postpartum mothers. The research sample was 30 people divided into 2 groups, namely 15 people as the experimental group and 15 people as the control group. With a purposive sampling technique. Data analysis with dependent T-test.

The results of univariate and bivariate analysis showed that the average duration of healing of perineal wounds in postpartum women who did postpartum exercise at BPM Siti Hajar, S.ST, Merak Batin Village, Natar District, South Lampung Regency in 2019, was 1.33 and in the control group was 4, 60 .

The conclusion is that there is an effect of postpartum gymnastics on the healing of perineal wounds in postpartum mothers at BPM Siti Hajar, S.ST, Merak Batin Village, Natar District, South Lampung Regency in 2019. The $t$ test results obtained $p$ value $0.000<a(0.05)$.

Suggestion it is recommended for health workers, especially midwives, to advise postpartum mothers to do postpartum exercise as an alternative to accelerate the healing of perineal wounds.
\end{abstract}

Keywords: Postpartum exercise, Perineal Wound Healing

\section{ABSTRAK}

Latar Belakang Persalinan dan kelahiran merupakan kejadian fisiologis. Seringkali persalinan menyebabkan perlukaan jalan lahir sehingga harus dirawat dengan baik dan benar Angka kematian ibu di Lampung tahun 2017 masih tinggi yaitu sebesar 115,8 per 100.000 kelahiran hidup.Hasil survey awal pada Bulan Januari 2019 di BPM Siti Hajar, S.ST Desa Merak Batin Kecamatan Natar Kabupaten Lampung Selatan, bahwa pada bulan januari terdapat 52 ibu post partum, dari 52 ibu post partum tersebut 40 diantaranya mengalami luka perineum, 37 dikarenakan rupture spontan dan 3 karena episiotomi.

Tujuan untuk mengetahui pengaruh Senam Nifas Terhadap Penyembuhan Luka Perineum Pada Ibu Nifas di BPM Siti Hajar, S.ST Desa Merak Batin Kecamatan Natar Kabupaten Lampung Selatan Tahun 2019.

Metode Jenis Penelitian Kuantitatif, rancangan penelitian pre-eksperimen dengan pendekatan static group comparison. Populasi sebanyak 52 ibu nifas. Sampel penelitian 30 orang yang di bagi dalam 2 kelompok yaitu 15 orang sebagai kelompok eksperimen dan 15 orang sebagai kelompok kontrol. Dengan teknik sampling purposive sampling. Analisa data dengan uji T-test dependent.

Hasil analisa univariat dan bivariate didapatkan rata-rata lama penyembuhan luka perineum pada ibu nifas yang melakukan senam nifas di BPM Siti Hajar, S.ST Desa Merak Batin Kecamatan Natar Kabupaten Lampung Selatan Tahun 2019, yaitu sebesar 1,33 dan pada kelompok kontrol sebesar 4, 60.

Kesimpulan diketahui ada Pengaruh Senam Nifas Terhadap Penyembuhan Luka Perineum Pada Ibu Nifas di BPM Siti Hajar, S.ST Desa Merak Batin Kecamatan Natar Kabupaten Lampung Selatan Tahun 2019. Hasil ujit didapat $p$ value $0,000<a(0,05)$. 
Saran bagi tenaga kesehatan khususnya bidan agar menganjurkan kepada ibu nifas agar melakukan senam nifas sebagai salah satu alternatif mempercepat penyembuhan luka perineum.

Kata Kunci : Senam nifas, Penyembuhan Luka Perineum

\section{PENDAHULUAN}

Masa nifas merupakan hal penting untuk diperhatikan guna menurunkan angka kematian ibu dan bayi di Indonesia.Dari berbagai pengalaman dalam menanggulangi kematian ibu dan bayi di banyak Negara, para pakar kesehatan menganjurkan upaya pertolongan difokuskan pada periode intrapartum. Upaya ini terbukti telah menyelamatkan lebih dari separuh ibu bersalin dan bayi baru lahir disertai dengan penyulit proses persalinan atau komplikasi yang mengancam keselamatan jiwa. Namun, tidak semua intervensi yang sesuai bagi suatu Negara dapat dengan serta merta dijalankan dan memberi dampak menguntungkan bila diterapkan di Negara lain. (Nanny, 2011).

Kemampuan penyelenggaraan kesehatan suatu negara di ukur dengan menentukkan tinggi rendahnya angka kematian ibu dan perinatal dalam 100.000 persalinan hidup. Menurut World Organization Organization (WHO), kematian maternal kematian seorang wanita waktu hamil atau dalam 42 hari sesudah berakhirnya kehamilan oleh sebab apapun, terlepas dari tuanya kehamilan dan tindakan yang dilakukan untuk mengakhiri kehamilan.Persalinan dan kelahiran merupakan kejadian fisiologis. Seringkali persalinan menyebabkan perlukaan jalan lahir sehingga harus dirawat dengan baik dan benar.(Sarwono,2010)

Angka kematian ibu (AKI) sebagai salah satu indikator pembangunankesehatan, sampai saat ini masih tinggi di Indonesia, berdasarkan hasil reskesdas tahun 2018, angka kematian ibu di Indonesia masih tinggi yaitu sebesar 305 per 100.000 kelahiran hidup. (Kemenkes, 2018)

Faktor langsung penyebab tingginya angka kematian ibu adalah perdarahan (30,3\%), terutama perdarahan post partum. Selain itu adalah hipertensi $(27,1 \%)$, infeksi $(7,3 \%)$, dan partus lama/macet $(1,7 \%)$. Komplikasi obstetrik umumnya terjadi pada waktu persalinan, yang waktunya pendek yaitu sekitar 8 jam.(Riskesdas, 2018).

Angka kematian ibu di Lampung tahun 2017 masih tinggi yaitu sebesar 115,8 per 100.000 kelahiran hidup (Dinas Kesehatan Provinsi Lampung, 2017). Bila dilihat berdasarkan kasus kematian yang ada di Provinsi Lampung tahun 2017 berdasarkan laporan dari kabupaten terlihat bahwa kasus kematian ibu yaitu terjadi selama (kematian ibu pada saat hamil, saat melahirkan dan nifas) seluruhnya sebanyak 179 kasus dimana kasus kematian ibu terbesar ( 59,78\%) terjadi pada saat persalinan dan $70,95 \%$ terjadi pada usia 20 - 34 tahun (Profil Dinkes Lampung, 2017).

Perlukaan jalan lahir dapat mengakibatkan infeksi pada daerah antara lubang vagina dan anus, bagian luar alat kelamin, vagina serta mulut rahim dan biasanya akan timbul gejala seperti: rasa nyeri serta panas pada tempat terinfeksi, kadang-kadang rasa perih muncul bila buang air kecil karena sudah merambat pada saluran kandung kencing dan sering juga disertai demam (Prawirahardjo, 2009).

Infeksi perlukaan jalan lahir ini bisa terjadi karena ibu tidak memperhatikan personal hygiene yang baik, belum mengerti cara perawatan luka perineum yang benar, belum mengerti manfaat dan tujuan dari perawatan luka perineum, serta kurang telaten dalam melakukan perawatan pasca persalinan. Kasus infeksi ini disebabkan juga karena infeksi yang terlokalisir di jalan lahir dan penyebab terbanyak dan lebih dari $50 \%$ adalah kuman Streptococcus anaerob yang sebenarnya tidak patogen dan merupakan penghuni jalan lahir namun karena adanya luka memungkinkan kuman ini untuk menyebabkan infeksi. (Sarwono 2010)

Pada umumnya robekan jalan lahir terjadi pada persalinan dengan trauma.pertolongan persalinan yang semakin manipulatif dan traumatik akan memudahkan robekan jalan lahir dan karena itu dihindarkan memimpin persalinan pada saat pembukaan serviks belum lengkap. Robekan jalan lahir biasanya akibat episiotomi, robekan spontan perineum, trauma forceps atau vakum ektraksi, atau karena versi ekstraksi (Sarwono, 2010).

Penghambat keberhasilan penyembuhanluka adalah sebagai berikut : malnutrisi, merokok, kurang tidur,stress, kondisi medis dan terafi, apusankurang optimal, lingkungan optimal untukpenyembuhan luka, kurang mobilisasi daninfeksi (Antini, 2016). Menurut santika 2020 perbaikan gizi merupakan salah satu kunci dari penyembuhan luka. Ibu nifas dianjurkan makan dengan diit seimbang, cukup karbohidrat, protein, lemak, vitamin dan mineral.

Beberapa manfaatsenam nifas secara umum adalah membantu penyembuhan rahim, perut, danotot pinggul yang mengalami trauma serta mempercepat kembalinya bagian-bagian tersebut ke bentuk normal, membantu menormalkan sendi-sendi 
yang menjadi longgar akibat kehamilan dan persalinan serta mencegah pelemahan dan peregangan lebih lanjut, mengahasilkan manfaat psikologis, menambah kemampuan menghadapi stress dan bersantai sehingga mengurangi depresi masa nifas.Mobilisasi yang efektif dilakukan untuk ibu nifas dalam mempercepat proses penyembuhan luka perineum dengan senam nifas, diantaranya untuk memperbaiki sirkulasi darah, memperbarui sikap tubuh, memperbaiki otot pelvis/ dasar panggul seorang perempuan. Berdasarkan hasil penelitian Paulfine 2007 didapatkan latihan dasar panggul pada ibu hamil dan ibu nifas merupakan potensi yang baik (Antini, 2016).

Senam nifas dapat mempercepat penyembuhan luka perineum, penyembuhan luka jaitan perineum dipengaruhi oleh banyak faktor, salah satunya adalah suplai darah yang mengandung $\mathrm{O} 2$ dan nutrien kejaringan luka, kontraksi dan relaksasi yang dihasilkan pada senam nifas dapat meningkatkan suplai darah kejaringan yang luka tersebut sehingga luka perineum cepat sembuh (Antini, 2016).

Hasil survey awal pada Bulan Januari 2019di BPM Siti Hajar, S.ST Desa Merak Batin Kecamatan Natar Kabupaten Lampung Selatan, bahwa pada bulan januari terdapat 52 ibu post partum, dari 52 ibu post partum tersebut 40diantaranya mengalami luka perineum, 37 dikarenakan rupture spontan dan 3 karena episiotomi.

Berdasarkan latar belakang diatas dan fenomena yang terjadi dilapangan peneliti tertarik untuk melakukan penelitian tentang "Pengaruh Senam Nifas Terhadap Penyembuhan Luka Perineum Pada lbu Nifas di BPM Siti Hajar, S.ST Desa Merak Batin Kecamatan Natar Kabupaten Lampung Selatan Tahun 2019"

\section{Metodologi Penelitian}

Jenis penelitian ini merupakan penelitian kuantitatif yaitu penelitian yang mencoba menggali bagaimana dan mengapa fenomena kesehatan itu terjadi. Penelitian ini merupakan penelitian analitik, yaitu penelitian ilmiah yang sistematis terhadap bagian-bagian dan fenomena serta hubungan hubungannya (Machmud, 2016). Penelitian ini telah dilakukan pada bulan Febuari-Juni 2019. Lokasi penelitian akan dilakukan di BPM Siti Hajar, S.ST Desa Merak Batin Kecamatan Natar Kabupaten Lampung Selatan

Jenis penelitian yang digunakan dalam penelitian ini adalah penelitian secara analitik dengan menggunakan rancangan cross-sectional yang merupakan rancangan penelitian dengan menggunakan pengukuran atau pengamatan pada saat bersamaan (sekali waktu) antara variabel bebas (faktor resiko) dengan variabel tergantung (efek) (Notoatmodjo, 2012).

Populasi dalam penelitian ini adalah semua ibu bersalin di BPM Siti Hajar, S.ST Desa Merak Batin Kecamatan Natar Kabupaten Lampung Selatan dimana rata-rata dalam sebulan sebanyak 52 ibu nifas dengan sampel 30 orang. 15 sebagai kelompok eksperimen dan 15 sebagai kelompok kontrol

Pengambilan sample penelitian ini dilakukan dengan menggunakan teknik purposve sampling yaitu mengambil sampel berdasarkan kriteria yang peneliti tentukan (Notoatmodjo, 2012). Analisa data menggunakan Analisa univariat dan bivariat dengan t-test independent

\section{HASIL PENELITIAN}

Berdasarkan tabel 1 didapatkan hasil usia ibu yang $<20$ tahun pada kelompok intervensi dan kelompok kontrol tidak ada, usia ibu 20-30 tahun pada kelompok intervensi sebanyak 11 orang $(73,3 \%)$ pada kelompok kontrol sebanyak 12 orang $(80.0 \%)$, usia ibu > 30 tahun pada kelompok intervensi sebanyak 4 orang $(26,7 \%)$ sedangkan pada kelompok kontrol sebanyak 3 orang $(20.0 \%)$.

Tabel 1.

Karakteristik Responden Berdasarkan Usia

\begin{tabular}{ccccc}
\hline Usia & \multicolumn{2}{c}{ Kelompok Intervensi } & \multicolumn{2}{c}{ Kelompok Kontrol } \\
\cline { 2 - 5 } (Tahun) & Frekuensi & Presentase $(\%)$ & Frekuensi & Presentase $(\%)$ \\
$<20$ & 0 & 0 & 0 & 0 \\
$20-30$ & 11 & 73.3 & 12 & 80.0 \\
$>30$ & 4 & 26.7 & 3 & 20.0 \\
Jumlah & 15 & 100.0 & 15 & 100.0 \\
\hline
\end{tabular}

Tabel 2.

Karakteristik Responden Berdasarkan Paritas 


\begin{tabular}{ccccc}
\hline Paritas & \multicolumn{2}{c}{ Kelompok Intervensi } & \multicolumn{2}{c}{ Kelompok Kontrol } \\
\cline { 2 - 5 } & Frekuensi & Presentase $(\%)$ & Frekuensi & Presentase (\%) \\
Primipara & 5 & 33.3 & 6 & 40.0 \\
Multipara & 10 & 66.7 & 9 & 60.0 \\
Jumlah & 15 & 100.0 & 15 & 100.0 \\
\hline
\end{tabular}

Berdasarkan tabel 2 didapatkan hasil paritas ibu yang primipara pada kelompok intervensi sebanyak 5 orang $(33,3 \%)$ pada kelompok kontrol sebanyak 6 orang (40.0\%), multipara pada kelompok intervensi sebanyak 10 orang $(66,7 \%)$ sedangkan pada kelompok kontrol sebanyak 9 orang $(60.0 \%)$.

\section{Uji Normalitas}

Uji Normalitas data bertujuan untuk mendeteksi distribusi data dalam suatu variabel yang akan digunakan dalam penelitian. Data yang baik dan layak untuk membuktikan model-model penelitian tersebut adalah data yang memiliki distribusi normal.Cara untuk mendeteksi normalitas distribusi data, salah satunya menggunakan uji Shapiro-whilk. Pengambilan keputusan yang diajukan adalah:

a) Jika angka Sig. Uji Shapiro-whilk> 0,05 maka data berdistribusi normal.

b) Jika angka Sig. Uji Shapiro-whilk< 0,05 maka data tidak berdistribusi normal.

Dengan menggunakan alat bantu olah data SPSS versi 16.0, diperoleh output sebagai berikut:
Tabel 3.

Uji Normalitas

\begin{tabular}{cc}
\hline & Shapiro-whilk \\
\cline { 2 - 2 } & Sig. \\
\hline Kelompok Intervensi & 0.107 \\
Kelompok Kontrol & 0.115 \\
\hline
\end{tabular}

Tabel diatas menunjukan bahwa uji normalitas menggunakan Shapiro-whilkpada variabel, kelompok intervensi sebesar 0.107 dan kelompok kontrol sebesar 0.115 karena nilai $P>0.05$ maka dapat disimpulkan semua data berarti data berdistribusi normal.

\section{Analisis Univariat}

Analisa univariat dilakukan pada tiap variable dalam bentuk tabel distribusi statistik deskriptif ratarata lama penyembuhan luka perineum pada ibu nifas yang melakukan senam nifas di BPM Siti Hajar, S.ST Desa Merak Batin Kecamatan Natar Kabupaten Lampung Selatan Tahun 2019.

Tabel 4.

Rata-rata lama penyembuhan luka perineum pada ibu nifas yang melakukan senam nifas di BPM Siti Hajar, S.ST Desa Merak Batin Kecamatan Natar Kabupaten Lampung Selatan Tahun 2019.

\begin{tabular}{ccccccc}
\hline Variabel & N & Mean & Median & SD & Min & Max \\
\hline $\begin{array}{c}\text { Lama Penyembuhan Luka } \\
\text { Perineum Kelommpok Senam Nifas }\end{array}$ & 15 & 1,33 & 1,00 & 0,488 & 1 & 2 \\
\hline
\end{tabular}

Berdasarkan tabel 4 diatas dapat diketahui bahwa dari 15 responden penelitian, diperoleh hasil nilai mean atau nilai rata-rata lama penyembuhan luka perineum dengan senam niafas yaitu 1,33 dengan nilai median 1,00 , standar deviasi sebesar 0,488 , nilai minimal sebesar 1 dan maksimal sebesar 2 .

Tabel 5.

Rata-rata lama penyembuhan luka perineum pada ibu nifas yang tidak melakukan senam nifas di BPM Siti Hajar, S.ST Desa Merak Batin Kecamatan Natar Kabupaten Lampung Selatan Tahun 2019.

\begin{tabular}{ccccccc}
\hline Variabel & N & Mean & Median & SD & Min & Max \\
\hline $\begin{array}{c}\text { Lama Penyembuhan Luka Perineum } \\
\text { pada Kelompok Kontrol }\end{array}$ & 15 & 4,60 & 5,00 & 0,507 & 4 & 5 \\
\hline
\end{tabular}

Berdasarkan tabel 5 diatas dapat diketahui bahwa dari 15 responden penelitian, diperoleh hasil nilai mean atau nilai rata-rata lama penyembuhan luka perineum pada kelompok kontrol yaitu 4,60 dengan nilai median 5,00 , standar deviasi sebesar 
0,507 , nilai minimal sebesar 5 dan nilai maksimal sebesar 5 .

\section{Analisis Bivariat}

Analisa bivariat uji $t$ test sample independent untuk mengetahui Pengaruh Senam Nifas Terhadap
Penyembuhan Luka Perineum Pada lbu Nifas di BPM Siti Hajar, S.ST Desa Merak Batin Kecamatan Natar Kabupaten Lampung Selatan Tahun 2019. Hasil analisa bivariat ditampilkan dalam bentuk table sebagai berikut:

Tabel 6.

Pengaruh Senam Nifas Terhadap Penyembuhan Luka Perineum Pada Ibu Nifas di BPM Siti Hajar, S.ST Desa Merak Batin Kecamatan Natar Kabupaten Lampung Selatan Tahun 2019.

\begin{tabular}{lcccc}
\hline $\begin{array}{c}\text { Penyembuhan Luka } \\
\text { Perineum }\end{array}$ & N & Mean & SD & P value \\
\hline Kelompok Intervensi & 15 & 1,33 & 0,488 & 0.000 \\
Kelompok Kontrol & 15 & 4,60 & 0,507 & \\
\hline
\end{tabular}

Berdasarkan tabel 6 diatas, didapatkan hasil nilai $p$-value sebesar $0,000<0,05$ yang berarti ada Pengaruh Senam Nifas Terhadap Penyembuhan Luka Perineum Pada Ibu Nifas di BPM Siti Hajar, S.ST Desa Merak Batin Kecamatan Natar Kabupaten Lampung Selatan Tahun 2019.

\section{PEMBAHASAN Univariat}

Hasil penelitian didapatkan bahwa dari 15 responden penelitian, diperoleh hasil nilai diperoleh hasil nilai mean atau nilai rata-rata lama penyembuhan luka perineum dengan senam niafas yaitu 1,33 dengan nilai median 1,00 , standar deviasi sebesar 0,488 , nilai minimal sebesar 1 dan maksimal sebesar 2. Sedangkan pada kelompok kontrol diperoleh hasil nilai mean atau nilai rata-rata lama penyembuhan luka perineum pada kelompok kontrol yaitu 4,60 dengan nilai median 5,00 , standar deviasi sebesar 0,507 , nilai minimal sebesar 5 dan nilai maksimal sebesar 5 .

Hasil penelitian ini sejalan dengan penelitian yang telah dilakukan olehAnita Ri Sukisno (2014) dengan judul Lama Penyembuhan Luka Perineum Pada Ibu Post Partum Yang Melakukan Senam Nifas Di Polindes Ngembeh Dlanggu Kabupaten Mojokerto, dengan hasil penelitian menunjukkan bahwa lama penyembuhan luka perineum pada ibu post partum yang melakukan senam nifas di Polindes Ngembeh Dlanggu Kabupaten Mojokerto diperoleh data sebagian besar responden mengalami penyembuhan dalam waktu yang normal (6-7 hari) sebanyak 14 responden $(60,9 \%)$.

Sesuai dengan teori menurut mela dkk, (2018), bahwa penyembuhan luka merupakan panjang waktu proses pemulihan pada kulit karena adanya kerusakan atau disintegritas jaringan kulit.

Menurut Rismawati (2012), bahwa penyembuhan luka dapat terjadi dalam beberapa fase yaitu slah satunya merupakan Fase Maturasi ( 5 hari sampai berbulan-bulan), Pada fase ini terjadi proses pematangan yang terdiri atas penyerapan Kembali jaringan yang berlebih, pengerutan sesuai dengan gaya gravitasi dan akhirnya perupaan kembali jaringan yang baru terbentuk. Fase ini dinyatakan berakhir jika semua tanda radang sudah hilang dan bisa berlangsung berbulan-bulan. Tubuh berusaha menormalkan kembali semua yang menjadi abnormal karena proses penyembuhan. Oedema dan sel radang diserap, sel muda menjadi matang, kapiler baru menutup dan diserap kembali, kolagen yang berlebih diserap dan sisanya mengerut sesuai dengan regangan yang ada.Selama proses ini dihasilkan jaringan parut yang pucat, tipis, lemas dan mudah digerakkan dari dasar. Terlihat pengerutan yang maksimal pada luka.Pada akhir fase ini, perupaan luka kulit mampu menahan regangan kira-kira $80 \%$ kemampuan kulit normal (Sjamsuhidajat, 2004).

Tulas (2017), menyebutkan bahwa penyembuhan luka perineum dapat di pengaruhi oleh nutrisi yang adekuat, kebersihan, istirahat, posisi, umur, penanganan jaringan, hemoragi, hipovolemia, edema, defisit oksigen, penumpukan drainase, medikasi, overaktifitas, gangguan sistemik, status imunosupresi, stres luka. Menurut Sakinah (2017), bahwa status nutrisi, merokok, usia, obesitas, diabetes mellitus, kortikosteroid, obatobatan, gangguan oksigenasi, infeksi, dan stress luka dapat memengaruhi proses penyembuhan luka. Dari Boyle (2009), menyatakan bahwa penyembuhan luka dipengaruhi oleh malnutrisi, merokok, kurang tidur, stres, kondisi medis dan terapi, asuhan kurang optimal, infeksi, dan apusan luka.

Menurut telaah peneliti, berdasarkan hasil penelitian didapatkan hasil lama luka perineum pada kelompok intervensi lebih baik dibandingkan dengan 
kelompok kontrol, sedangkan hasil penyembuhan luka pada responden berbeda-beda hal tersebut disebabkan oleh faktor paritas ibu, dimana ibu dengan paritas lebih dari satu akan mengalami penyembuhan luka yang lebih baik dibandingkan dengan ibu dengan paritas ibu satu hal tersebut disebabkan karena ibu dengan paritas lebih dari satu sudah memiliki pengalaman sebelumnya dalam melakukan perwatan luka perineum sehingga penyembuhan luka lebih bagus. Selain itu disebebkan juga oleh faktor nutrisi yang dikonsumsi oleh ibu berbeda-beda sehingga hasilnya berbedabeda pula.

\section{Bivariat}

Hasil analisa data menggunakan uji T-Test Independent didapatkan nilai $p$ value $(0.000)<$ alpha $(0,05)$ berarti $\mathrm{H}_{0}$ ditolak maka dapat disimpulkan adaPengaruh Senam Nifas Terhadap Penyembuhan Luka Perineum Pada Ibu Nifas di BPM Siti Hajar, S.ST Desa Merak Batin Kecamatan Natar Kabupaten Lampung Selatan Tahun 2019.

Hasil penelitian ini sejalan dengan penelitian yang telah dilakukan olehAnita Ri Sukisno (2014) dengan judul Lama Penyembuhan Luka Perineum Pada Ibu Post Partum Yang Melakukan Senam Nifas Di Polindes Ngembeh Dlanggu Kabupaten Mojokerto, dengan hasil penelitian menunjukkan bahwa lama penyembuhan luka perineum pada ibu post partum yang melakukan senam nifas di Polindes Ngembeh Dlanggu Kabupaten Mojokerto diperoleh data sebagian besar responden mengalami penyembuhan dalam waktu yang normal (6-7 hari) sebanyak 14 responden $(60,9 \%)$. Menurut Rismawati (2012), bahwa penyembuhan luka dapat terjadi dalam beberapa fase yaitu slah satunya merupakan Fase Maturasi (5 hari sampai berbulan-bulan), Pada fase ini terjadi proses pematangan yang terdiri atas penyerapan Kembali jaringan yang berlebih, pengerutan sesuai dengan gaya gravitasi dan akhirnya perupaan kembali jaringan yang baru terbentuk. Fase ini dinyatakan berakhir jika semua tanda radang sudah hilang dan bisa berlangsung berbulan-bulan. Tubuh berusaha menormalkan kembali semua yang menjadi abnormal karena proses penyembuhan. Oedema dan sel radang diserap, sel muda menjadi matang, kapiler baru menutup dan diserap kembali, kolagen yang berlebih diserap dan sisanya mengerut sesuai dengan regangan yang ada. Selama proses ini dihasilkan jaringan parut yang pucat, tipis, lemas dan mudah digerakkan dari dasar. Terlihat pengerutan yang maksimal pada luka.Pada akhir fase ini, perupaan luka kulit mampu menahan regangan kira-kira $80 \%$ kemampuan kulit normal(Rismawati,2012).

Smeltzer (2002), menyebutkan bahwa penyembuhan luka perineum dapat di pengaruhi oleh nutrisi yang adekuat, kebersihan, istirahat, posisi, umur, penanganan jaringan, hemoragi, hipovolemia, edema, defisit oksigen, penumpukan drainase, medikasi, overaktifitas, gangguan sistemik, status imunosupresi, stres luka. Menurut Johnson \& Taylor (2005), bahwa status nutrisi, merokok, usia, obesitas, diabetes mellitus, kortikosteroid, obatobatan, gangguan oksigenasi, infeksi, dan stress luka dapat memengaruhi proses penyembuhan luka. Dari Boyle (2009), menyatakan bahwa penyembuhan luka dipengaruhi oleh malnutrisi, merokok, kurang tidur, stres, kondisi medis dan terapi, asuhan kurang optimal, infeksi, dan apusan luka.

Beberapa manfaatsenam nifas secara umum adalahmembantu penyembuhan rahim, perut, danotot pinggul yang mengalami trauma serta mempercepat kembalinya bagian-bagian tersebut ke bentuk normal, membantu menormalkan sendi-sendi yang menjadilonggar akibat kehamilan dan persalinan serta mencegah pelemahan dan peregangan lebih lanjut, mengahasilkan manfaat psikologis, menambah kemampuan menghadapi stress dan bersantai sehingga mengurangi depresi masa nifas.Mobilisasi yang efektif dilakukan untukibu nifas dalam mempercepat proses penyembuhan luka perineum dengan senam nifas, diantaranya untuk memperbaiki sirkulasi darah, memperbaruisikap tubuh, memperbaiki otot pelvis/ dasar panggul seorang perempuan. Berdasarkan hasil penelitian Paulfine 2007 didapatkan latihan dasar panggulpada ibu hamil dan ibu nifas merupakan potensi yang baik (Antini, 2016).

Senam nifas dapat mempercepat penyembuhan luka perineum, penyembuhan luka jaitan perineum dipengaruhi oleh banyak faktor, salah satunya adalah suplai darah yang mengandung $\mathrm{O} 2$ dan nutrien kejaringan luka, kontraksi dan relaksasi yang dihasilkan pada senam nifas dapat meningkatkan suplai darah kejaringan yang luka tersebut sehingga luka perineum cepat sembuh (Antini, 2016).

Menurut telaah peneliti, berdasarkan hasil penelitian didapatkan hasil lama luka perineum pada kelompok intervensi lebih baik dibandingkan dengan kelompok kontrol, sedangkan hasil penyembuhan luka pada responden berbeda-beda hal tersebut disebabkan oleh faktor paritas ibu, dimana ibu dengan paritas lebih dari satu akan mengalami penyembuhan luka yang lebih baik dibandingkan dengan ibu dengan paritas ibu satu hal tersebut 
disebabkan karena ibu dengan paritas lebih dari satu sudah memiliki pengalaman sebelumnya dalam melakukan perwatan luka perineum sehingga penyembuhan luka lebih bagus. Selain itu disebebkan juga oleh faktor nutrisi yang dikonsumsi oleh ibu berbeda-beda sehingga hasilnya berbedabeda pula.

\section{KESIMPULAN}

Diketahui rata-rata lama penyembuhan luka perineum pada ibu nifas yang melakukan senam nifas di BPM Siti Hajar, S.ST Desa Merak Batin Kecamatan Natar Kabupaten Lampung Selatan Tahun 2019, yaitu sebesar 1,33.Diketahui rata-rata lama penyembuhan luka perineum pada ibu nifas yang tidak melakukan senam nifas di BPM Siti Hajar, S.ST Desa Merak Batin Kecamatan Natar Kabupaten Lampung Selatan Tahun 2019 yaitu sebesar 4,60.DiketahuiPengaruh Senam Nifas Terhadap Penyembuhan Luka Perineum Pada Ibu Nifas di BPM Siti Hajar, S.ST Desa Merak Batin Kecamatan Natar Kabupaten Lampung Selatan Tahun 2019, nilai $p$-value $0.000<\alpha(0.05)$.

\section{SARAN}

Sebagai bahan informasi bagi bidan bahwa waktu penyembuhan luka perineum dengan melakukan senam nifas dapat mempercepat penyembuhan luka perineum.Dapat menambah pengetahuan dan wawasan bagi peneliti tentang penyambuhan luka perineum dengan melakukan senam nifas pada luka perineum ibu postpartum. Dapat menjadi bahan informasi dan menambah pengetahuan serta wawasan bahwa dengan melakukan senam nifas dapat mempercepat penyembuhan luka perineum, sehingga diharapkan ibu-ibu postpartum dapat menggunakannya sebagai salah satu alternative penyembuhan luka perineum selain obat-obatan farmakologi. Dapat menambah wawasan penelitian selanjutnya dan dapat dijadikan bahan referensi guna melakukan penelitian yang sama, dan diharapkan peneliti selanjutnya yang akan melakukan penelitian yang sama dapat menambah variabel - variabel yang lain sehingga diperoleh hasil penelitian yang lebih baik lagi.

\section{DAFTAR PUSTAKA}

Anita Ri Sukisno. 2014. Lama Penyembuhan Luka Perineum Pada lbu Post Partum Yang Melakukan Senam Nifas Di Polindes Ngembeh Dlanggu Kabupaten Mojokerto.
Asih, Yusari \& Risneni. 2016. Asuhan Kebidanan Nifas dan Menyusui dilengkapi dengan evidance based practice, dan daftar tilik. Jakarta: TIM.

Kemenkes, R. I. (2018). Hasil utama RISKESDAS 2018. Online) http://www. depkes. go. id/resources/download/infoterkini/materi_rakorpop_2018/Hasil\% 20Riskesdas, 202018.

Machmud, M. (2016). Tuntunan Penulisan Tugas Akhir Berdasarkan Prnsip Dasar Penelitian IImiah. Research Report.

MELLA ROZA, P. (2018). PENGARUH SENAM NIFAS TERHADAP PENYEMBUHAN LUKA PERINEUM DERAJAT II PADA IBU POST PARTUM DI BPM MURTINAWITA KOTA PEKANBARU (Doctoral dissertation, Poltekkes Kemenkes Riau).

Nanny, Vivian Lia Dewi., \& Tri Sunarsih. 2011. Asuhan Kebidanan pada ibu Nifas. Jakarta: Salemba Medika.

Notoatmodjo,Soekidjo, 2012, Metode Penelitian Kesehatan. Jakarta;

Profil Dinas Kesehatan Provinsi Lampung,2017

Rismawanti, V. (2012). HUBUNGAN ANTARA SIKAP IBU NIFAS TERHADAP MAKANAN GIZI SEIMBANG DENGAN PENYEMBUHAN LUKA PERINEUM DI KLINIK BERSALIN KHAIRUNNISA TAHUN 2012. Bidan Prada: Jurnal Publikasi Kebidanan Akbid YLPP Purwokerto, 3(01).

SAKINAH, T. P. HUBUNGAN STATUS GIZI IBU NIFAS DAN BUDAYA MAKANAN PANTANGAN MASA NIFAS DENGAN PENYEMBUHAN LUKA PERINEUM DI RS DEWI SARTIKA KOTA KENDARI TAHUN 2017.

Sarwono, P. (2010). Ilmu kebidanan. Jakarta: Yayasan Bina Pustaka

Santika, V. W., Lathifah, N. S., \& Parina, F. (2020). PENGARUH PEMBERIAN TELUR REBUS DENGAN PERCEPATAN PENYEMBUHAN LUKA PERINEUM. Jurnal Kebidanan Malahayati, 6(2), 244-248.

Sulistyawati, Ari. 2009. Buku Ajar Asuhan Kebidanan pada ibu nifas. Jogyakarta: CV Andi Offset

Tulas, V. D. P., Kundre, R., \& Bataha, Y. (2017). Hubungan Perawatan Luka Perineum Dengan Perilaku Personal Hygiene Ibu Post 
Partum Di Rumah Sakit Pancaran Kasih Gmim Manado. Jurnal Keperawatan, 5(1).

Vivian Nanny Lia., \& Sunarsih, Tri.2011. Asuhan

Kebidanan pada Ibu

Salemba Medika
Wiknjosastro, Hanifa, 2009, IImu Kebidanan, Edisi Ketiga, Jakarta : YBP-SP. 